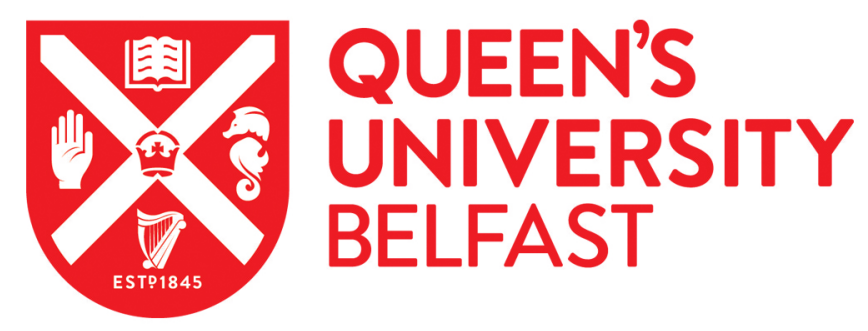

\title{
Innate Lymphoid Cells are the Predominant Source of Interleukin-17A During the Early Pathogenesis of Acute Respiratory Distress Syndrome
}

Muir, R., Osbourn, M., Dubois, A. V., Doran, E., Small, D. M., Monahan, A., O'Kane, C. M., McAllister, K.,

Fitzgerald, D. C., Kissenpfennig, A., McAuley, D. F., \& Ingram, R. J. (2016). Innate Lymphoid Cells are the

Predominant Source of Interleukin-17A During the Early Pathogenesis of Acute Respiratory Distress Syndrome. American Journal of Respiratory and Critical Care Medicine, 193(4), 407-416.

https://doi.org/10.1164/rccm.201410-1782OC

Published in:

American Journal of Respiratory and Critical Care Medicine

Document Version:

Peer reviewed version

Queen's University Belfast - Research Portal:

Link to publication record in Queen's University Belfast Research Portal

\section{Publisher rights}

Copyright ( 2015 by the American Thoracic Society

Originally Published in: Muir et al., Innate lymphoid cells are the predominant source of interleukin-17A during the early pathogenesis of acute respiratory distress syndrome, American Journal of Respiratory and Critical Care Medicine, 2015; Volume 193, Issue 4: Pages 407416.

DOI: $10.1164 / \mathrm{rccm} .201410-1782 \mathrm{OC}$

The final publication is available at http://www.atsjournals.org/doi/10.1164/rccm.201410-1782OC\#.Vop6lvmLRhE

\section{General rights}

Copyright for the publications made accessible via the Queen's University Belfast Research Portal is retained by the author(s) and / or other copyright owners and it is a condition of accessing these publications that users recognise and abide by the legal requirements associated with these rights.

Take down policy

The Research Portal is Queen's institutional repository that provides access to Queen's research output. Every effort has been made to ensure that content in the Research Portal does not infringe any person's rights, or applicable UK laws. If you discover content in the Research Portal that you believe breaches copyright or violates any law, please contact openaccess@qub.ac.uk. 


\section{Innate lymphoid cells are the predominant source of interleukin-17A during}

\section{the early pathogenesis of acute respiratory distress syndrome}

Roshell Muir ${ }^{1 \dagger}$, Megan Osbourn ${ }^{1 \dagger}$, Alice V. Dubois ${ }^{1}$, Emma Doran ${ }^{1}$, Donna M Small, Avril Monahan ${ }^{1}$, Cecilia M. O'Kane ${ }^{1}$, Katherine McAllister ${ }^{1}$, Denise C. Fitzgerald ${ }^{1}$, Adrien Kissenpfennig ${ }^{1}$, Daniel F. McAuley ${ }^{1,2}$, and Rebecca J. Ingram ${ }^{1 *}$.

${ }^{1}$ Centre for Infection and Immunity, Queen's University Belfast, 97 Lisburn Road, Belfast, UK. ${ }^{2}$ Regional Intensive Care Unit, Royal Victoria Hospital, Belfast, UK

${ }^{\dagger}$ These authors contributed equally to this work.

Concept and design: RJI, DFM, CO'K, RM. Laboratory analysis and interpretation: RM, MO, KM, AM AVD, ED, DMS. Manuscript preparation and significant intellectual input: RJI, DFM, CO'K, RM, AVD, DF, AK.

${ }^{*}$ Corresponding author; Dr. Rebecca Ingram, Centre for Infection and Immunity, Queen's University Belfast, 97 Lisburn Road, Belfast BT9 7AE, UK. Tel: +4428 9097 2090; Fax: +4428 9097 2671; E-mail address: b.ingram@qub.ac.uk. ${ }^{1}$

Running title; ILCs are the main source of IL-17 in ARDS

Descriptor number; 4.1 ALI/ARDS: Biological Mechanisms

${ }^{1}$ This work was funded by the Dina Korner Endowment Fund, Queen's University Belfast. R Muir and M Osbourn were supported by Department of Education and Learning (Northern Ireland) PhD studentships. 


\section{Abstract}

Rationale: IL-17A is purported to help drive early pathogenesis in acute respiratory distress syndrome (ARDS) by enhancing neutrophil recruitment. Whilst IL-17A is the archetypal cytokine of $\mathrm{T}$ helper (Th)17 cells, it is produced by a number of lymphocytes, the source during ARDS being unknown.

Objectives: To identify the cellular source and the role of IL17A in the early phase of lung injury

Methods: Lung injury was induced in WT (C57BL/6) and IL-17 KO mice with aerosolised LPS $(100 \mu \mathrm{g})$ or Pseudomonas aeruginosa infection. Detailed phenotyping of the cells expressing RORyt, the transcriptional regulator of IL-17 production, in the mouse lung at 24 hours was carried out by flow cytometry.

Measurement and Main Results: A 100-fold reduction in neutrophil infiltration was observed in the lungs of the IL-17A KO compared to wild type (WT) mice. The majority of RORyt ${ }^{+}$cells in the mouse lung were the recently identified type 3 innate lymphoid cells (ILC3). Detailed characterisation revealed these pulmonary ILC3s (pILC3s) to be discrete from those described in the gut. The critical role of these cells was verified by inducing injury in Rag2 $\mathrm{KO}$ mice which lack T cells but retain ILCs. No amelioration of pathology was observed in the Rag2 KO mice.

Conclusions: IL-17 is rapidly produced during lung injury and significantly contributes to early immunopathogenesis. This is orchestrated largely by a distinct population of pILC3 cells. Modulation of pILC3s' activity may potentiate early control of the inflammatory dysregulation seen in ARDS, opening up new therapeutic targets.

\section{Abstract word count 247}

Key Words: ARDS, acute lung injury, IL-17, lymphocyte, ILC3, pILC 


\section{Introduction}

Acute respiratory distress syndrome (ARDS) is characterised by a dysregulated inflammatory response and neutrophil infiltration (1). Murine models of lung injury have demonstrated that lymphocytes rapidly influx into the lung during the early phase (exudative phase) (2-5) and the lymphocyte derived pro-inflammatory cytokine interleukin (IL)-17A is believed to contribute to pathogenesis by augmenting neutrophil recruitment $(6-9)$. IL-17 is known to promote the production of various other inflammatory mediators including IL-6, IL-8, tumour necrosis factor (TNF)- $\alpha$, IL$1 \beta$, granulocyte-colony stimulating factor (G-CSF), monocyte chemoattractant protein (MCP)-1 (10). It is also known to directly drive the production of macrophage inflammatory protein (MIP)-2 (11).

Differentiation of lymphocytes towards a type 17 programme is dependent on the expression of the transcription factor RORyt $(12,13)$. Although IL-17 was first described as the signature cytokine of $\mathrm{CD} 4^{+} \mathrm{T}$ helper (Th)17 cells it is now known to also be secreted by cytotoxic $C D 8^{+} \mathrm{T}(\mathrm{Tc})$ cells, gamma delta $(\mathrm{\gamma} \delta) \mathrm{T}$ cells, invariant natural killer (iNK)T cells and CD3 natural killer (NK) cells (14). Recently, innate lymphoid cells (ILCs) have emerged as a key producer of IL-17 (15).

ILCs represent a family of developmentally related innate cells that are able to produce a broad range of cytokines. They have been ascribed a role in the defence of mucosal surfaces, as well as in tissue homeostasis and repair following infection and inflammation (16). ILCs require the common cytokine-receptor $\mathrm{Y}$-chain (cy) signalling (17) and IL-7R expression for their development and maintenance (18). Recently, a uniform nomenclature has been proposed to define sub-populations of 
ILCs based on phenotypical and functional characteristics (19). RORyt ${ }^{+}$ILCs, which express IL-17A, have been denoted as ILC3s. The essential role of ILC3s in both protection and immunopathology within the gut mucosa is now well recognised (16); however, their impact at other mucosal sites has not been reported in detail.

Whilst it has been supposed that IL-17A in the lung during the exudative phase of ARDS is $\mathrm{CD}^{+} \mathrm{T}$ cell derived (6-8), a comprehensive examination of the cellular source of this cytokine has not been performed. Thus, the aim of this study was both to substantiate the role of IL-17A in the early pathogenesis of lung injury and determine the source of this cytokine. We confirmed the critical role of IL-17A in neutrophil recruitment in IL-17 knock out (KO) mice and demonstrated that ILC3s represent the greatest proportion of the RORyt ${ }^{+}$cells within the lung during the acute phase of lipopolysaccharide (LPS)-induced lung injury. The ability of pulmonary ILC3s to drive neutrophil recruitment was confirmed in Rag2 KO mice, which lack all adaptive lymphocytes, including $T$ cells. This is the first reported demonstration of ILC3s contributing to pathogenesis within the lung.

Some of the results of these studies have been previously reported in the form of an abstract(s) (20-22). 


\section{Methods}

Additional methodological details available online.

\section{Animals}

Sex- and age- (6-14 weeks) matched C57BL/6 wild-type (WT) mice and IL-17A KO mice were bred in house. Recombinase activating gene 2-deficient knock out (Rag2 $\mathrm{KO}$ ) and Rag2 and the common cytokine receptor y chain (cy Rag2 DKO) mice were obtained from MRC National Institute for Medical Research, UK.

Induction of lung injury in mice.

Lung injury was induced in mice by the administration of either E. coli LPS (100 $\mu \mathrm{g})$ (Sigma, UK- serotype $0111: B 4)$ or $5 \times 10^{6}$ CFUs of Pseudomonas aeruginosa. Mice were anaesthetised and, unless otherwise stated, all mice were administered LPS orotracheally (o.t). Mice were intubated using a high-pressure syringe and MicroSprayer aerosoliser (Penn-Century. Inc. Wyndmoor, PA) and LPS or a saline control $(50 \mu \mathrm{l})$ delivered into the lung. For intra-nasal (i.n) administration, $20 \mu \mathrm{l}$ of LPS, bacteria or saline control were applied drop wise to the animal's nose and were inhaled by normal respiration. Mice were culled at $24 \mathrm{~h}$ post induction, unless otherwise stated. To calculate the lung indices, a measure of pulmonary inflammation, the following equation was used; Lung index = (lung weight/body weight experimental) / (lung weight/body weight control). 


\section{Lung Histology}

Lungs were excised and fixed in $10 \%$ formaldehyde and $3 \mu \mathrm{m}$ sections were cut, stained with Haematoxylin and eosin (H\&E) and mounted. A researcher blinded to the groups scored the damage to the lung (23).

\section{Quantification of inflammatory markers within the lung.}

Bronchoalveolar lavage fluid (BAL) was obtained by the instillation of $600 \mu \mathrm{l}$ of PBS. Lung homogenate was prepared by homogenising perfused lung in $500 \mu \mathrm{l}$ of PBS with a mechanical homogeniser (VWR, UK). The levels of IL-17A, IL-6, IL-23p19 (eBioscience, UK), keratinocyte-derived chemokine (KC), IL-2 (R\&D Systems, UK) and MIP-2 (Preprotech, USA) were determined by ELISA. Myeloperoxidase (MPO) activity was measured using amplifu red (Sigma-Aldrich, UK). Protein was quantified using Pierce BCA protein assay (Thermo Scientific, USA). Assays were read on a spectrophotometer (BioTek, USA).

\section{Isolation and preparation of lung cells}

Perfused lungs were harvested into Iscoves's Modified Dulbecco's Medium (IMDM) (Gibco, UK) supplemented with $10 \%$ fetal calf serum (FCS) (Source Bioscience, UK) and $1 \%$ penicillin/streptomycin (PAA, UK). The lung was finely minced and incubated at $37^{\circ} \mathrm{C}$ with $1 \mathrm{mg} / \mathrm{mL}$ Collagenase $D$ and $200 \mu \mathrm{g} / \mathrm{mL}$ DNase 1 (Roche, Germany). The samples were then passed through a $70 \mu \mathrm{m}$ cell strainer (Becton Dickinson, UK) to obtain a single cell suspension. 
Ex vivo cell stimulation

A single cell suspension was plated in IMDM media supplemented with $10 \%$ FCS and $1 \% \mathrm{P} / \mathrm{S}$, and stimulated with IL-23 (50 ng/ml), IL-7 (10 ng/ml) (Milteni, UK) or IL$2(10 \mathrm{ng} / \mathrm{ml})$ (Dynax, USA) or combinations of these cytokines. The cells were incubated at $37^{\circ} \mathrm{C}$ with $5 \% \mathrm{CO}_{2}$. At specific time points $(4,24,48$ and $72 \mathrm{~h})$, the cell culture supernatant $(750 \mu \mathrm{L})$ was removed and stored at $-80^{\circ} \mathrm{C}$ until analysis for IL17A by ELISA. At $72 \mathrm{~h}$ the cells were restimulated with a commercial stimulation cocktail (eBioscience, UK), to induce IL-17 production, and protein transport inhibitor cocktail (eBioscience, UK), to prevent cellular secretion of this IL-17. After $5 \mathrm{~h}$, the cells were analysed for the presence of intracellular IL-17, in combination with cell surface markers to identify specific cellular populations, using flow cytometry.

\section{Flow cytometry}

Cells were washed in FACS buffer (PBS, $2 \%$ FCS) and the cell pellets were blocked for 15 minutes at room temperature with anti-CD16/CD32 (eBioscience, UK). The cells were surface stained with specific antibodies (detailed in the supplementary methods), or an appropriate isotype control, to delineate the cellular populations (Figure E1). The cells were washed to remove any unbounded antibody and fixed/permeabilised (eBioscience, UK) overnight. Intracellular antibodies targeting RORyt (eBioscience, UK), IL-17A or an appropriate isotype control were applied. After incubation cells were washed, fixed and acquired on a FACSCanto II (Becton Dickinson, UK). Data analysis was performed using FlowJo software (FlowJo Inc, OR, USA) 
Quantitative Real Time PCR

Lung injury was induced with LPS in WT, Rag2 KO and cy Rag2 DKO mice and the lungs were collected at $4 \mathrm{~h}$. RNA was extracted using TRIzol reagent (Life Technologies, UK), transcription and quantitative PCR were conducted using the Superscript III Platinum One-Step kit (Life technologies, UK), with TaqMan probes on a Stratagene MX3005P real-time PCR machine (Aligent Technologies, Germany). The fold change in IL-17A gene expression levels, relative to a PBS-treated control, and normalised to the housekeeping gene YWHAZ, was calculated using the $2^{-\triangle \triangle C T}$ method (24).

\section{Statistical Analyses}

Nonparametric data was normalised prior to analysis, results were compared using Student's t-test or one-way ANOVA. The exception to this is the real-time PCR analysis in which a Kruskal-Wallis test was used. Graphic data represents the mean ( \pm SEM). 


\section{Results}

IL-17A plays a significant role in recruiting neutrophils to the lung

The role of IL-17 in the early immunopathogenesis of acute lung injury was investigated by comparing the responses of WT (C57BL/6) or IL-17A KO mice in a murine model of LPS induce lung injury. Histological examination of the lungs demonstrated that, in WT mice LPS treatment resulted in diffuse cellular infiltration, whilst in the IL-17 KO lungs there were only patchy foci of inflammation (Figure 1A). Scoring of the lung damage observed histologically (23) revealed that there was significantly less injury in the IL-17 KO mice $(p=0.04)$ (Figure 1B). No injury was observed in the saline treated controls of either strain (Figures $1 A \& B$ ). There was decreased pulmonary inflammation in the $\mathrm{IL}-17 \mathrm{KO}$ mice as illustrated by a significant reduction in the lung index $(p=0.009)$ (Figure $1 C)$. Reduced protein within the BAL $(p=0.04)$ (Figure 1D) indicates a reduction in oedema in the IL-17 KO mice. A significant, 100 -fold reduction in the numbers of neutrophils recruited into the lungs was observed in IL-17A KO mice in comparison to WT mice $(p=0.03)$ (Figure 1E). There was also a significant reduction in myeloperoxidase (MPO) levels $(p=0.05)$ (Figure 1F), a marker of neutrophil activity (25).

IL-6 was significantly lower in the IL-17 KO mice $(p=0.04)$ (Figure $1 G)$ than in the WT controls. Levels of KC, the murine homolog of IL-8, were not significantly reduced $(p=0.09)$ (Figure $1 \mathrm{H})$, however, levels of the IL-17 dependant neutrophil chemoattractant MIP-2 (11) were significantly reduced $(p=0.01)$ (Figure 1I).

IL-17 driven recruitment of neutrophils into the lung was also apparent when bacterial pneumonia was used to induce lung injury. There was a significant reduction in the 
percentage of neutrophils detected within the BAL $(p=0.005)$ (Figure $2 A)$. Again, demonstrating the downstream effects of IL-17, a significant reduction in the levels of MIP-2 $(p=0.04)$ were observed (Figure $2 B)$. The diminished neutrophilia within the lung resulted in a trend towards reduced damage, indicated by protein levels in the BAL $(p=0.052)$ (Figure $2 C)$, and disease severity (IL-6 $p=0.1)$ (Figure $2 D)$. There was no significant difference in the bacterial burden within the lungs of the WT and IL-17 KO mice (data not shown).

ILCs are the predominant RORyt ${ }^{+}$cells detected within the lung during the acute phase of lung injury.

To establish the cellular source of the IL-17, injury was induced in C57BL/6 mice and lung cells were harvested 24 hours post administration. The expression of RORyt, was determined using flow cytometry. LPS administration resulted in a significant increase in the number of RORyt ${ }^{+}$cells $(p=0.001)$ within the lung, in comparison to PBS treated control mice (Figure 3A). When the phenotype of the gated RORyt ${ }^{+}$cells was examined, the frequency of NKT, NK and $y \delta T$ RORyt ${ }^{+}$cells was low (Figure 3B \& E1). The lung leukocyte RORyt ${ }^{+}$population consisted predominantly of ILC (28.6 \% $\pm 5.9)$ and $\alpha \beta T$ cells $(30.9 \% \pm 10.1)$ (Figure $3 B$ \& E1). The $\alpha \beta T$ cells were equally divided between $\mathrm{CD}^{+}(\mathrm{Th17})$ and $\mathrm{CD} 8^{+}(\mathrm{Tc17})$ cells $(\mathrm{p}=0.43)$ (Figure. 3B \& E1). To further verify IL-17 production in the RORyt ${ }^{+}$cells, injury was induced and the lungs were harvested. The cells were rested and then restimulated ex-vivo to induce a further burst of IL-17 production. Golgi block prevented cellular release of the IL-17, thus allowing the identification of $\mathrm{IL}-17^{+}$cells. Both RORyt ${ }^{+} \mathrm{ILCs}$ and $\mathrm{CD} 4+\mathrm{T}$ cells produced IL-17A but this was not observed in $\mathrm{CD}^{+}$cells (Figure 3C). 
A significant augmentation of the ILC3 population was observed in the lung post-LPS exposure $(p=0.01)$ (Figure $4 A)$ and these cells far outnumbered the Th17 cells detected in the lung $(p=0.009)$ (Figure 4B). However, no significant difference in the median fluorescence intensity of IL-17A expression, an indicator of production per cell, was detected between the CD4 ${ }^{+}$cells and ILCs stimulated ex vivo $(p=0.9)$ (Figure 4C), indicating ILC3s are the predominant source of IL-17.

To further verify that ILC3s are the critical source of IL-17, RNA expression levels were examined in WT, Rag2 KO (lacking T cells, but retaining ILCs) and cy Rag2 DKO (lacking both T cells and ILCs) mice using quantitative real-time PCR. In the cy Rag2 mice in which both adaptive and innate lymphocytes are absent (cy Rag2 DKO) IL-17A (Figure 5A) was not detected. When ILCs are present (Rag2 KO) mice, IL-17 expression was not significantly different from the WT controls $(p=0.4)$ (Figure $5 A)$. Furthermore, there was no significant difference in the lung index $(p=0.5)$ (Figure 5B) or IL-17 induced cytokine MIP-2 ( $p=0.2)$ (Figure $5 \mathrm{C}$ ), in Rag2 KO mice compared to WT controls. The Rag2 KO mice showed elevated levels of neutrophil infiltration $(p=0.02), K C$ levels $(p=0.002)$ and a trend towards increased IL-6 $(p=$ 0.06) following LPS induced lung injury.

IL-17A production in lung lymphocytes is induced by IL-23 and amplified by IL-2.

IL-23 is known to drive IL-17 production (14), whilst IL-2 and IL-7 both utilise the cytokine-receptor common $y$-chain known to be involved in ILC signalling (17). To examine the regulation of IL-17 production in ILC3s, cells were harvested from the lungs of LPS exposed mice and cultured in the presence of rlL-23, rlL-2 and rIL-7 or combinations thereof. The levels of IL-17A in the cell culture supernatant at 4, 24, 48 
and $72 \mathrm{~h}$ were quantified by ELISA. IL-17A production continued to increase up to 72 h (Figure 6A). No significant difference was observed in IL-17A levels when the cells were stimulated with all three cytokines or with just IL-23 and IL-2 $(p=0.94)$ (Figure $6 \mathrm{~B}$ ), suggesting there is little role for IL-7 in induction of IL-17A production by ILC3s in this model. Whilst IL-23 alone induced IL-17A release, this was significantly augmented when IL-2 was added $(p=0.004)$ (Figure 6B). To verify that the IL-2 was not preferentially driving $T$ cell production of IL-17A, intracellular flow cytometry was used to demonstrate IL-17A production by the ILC3s after $72 \mathrm{~h}$ stimulation. No differences were observed in the contribution of $T$ cells to the IL-17A production when the cells were stimulated with IL-2 compared to IL-23 (Figure 6C). When ILC3s were cultured with IL-2 there was a significant increase in the percentage of cells expressing the receptor for IL-23 $(p=0.03)$ (Figure $6 \mathrm{D})$. Following the induction of acute lung injury in vivo, elevated levels of IL-23p19 were detected in murine BAL ( $p$ $=0.04$ ) (Figure 6E). A significant elevation in IL-2 levels is observed in the mice at 12 $h$ in LPS-treated mice compared to control-treated animals ( $p=0.02$ ) (Figure 6F).

\section{Phenotypic analysis of the lung ILCs}

To further phenotype the RORyt ${ }^{+}$ILCs in the lung during LPS induced lung injury, a detailed characterisation of the expression of a number of surface receptors was carried out. We identified a population of cells within the lung during the exudative phase of lung injury that were defined as ILC3 based on the lack of expression of lineage markers ( $\mathrm{Lin}^{-}$) and expression of CD45 and RORyt (Figure E2A). The expression of ILC surface markers on these cells was characterised (Figure E2B-G \& Table 1). The most abundant RORyt ${ }^{+}$ILCs characterised resembled the NCR-' ILC3s (58 \%) described in the gut (12), with the exception that the cells detected in the lung 
were CD117 (c-KIT) positive. The second most frequent cell type had the surface marker expression profile described for LTi cells (21\%) (26). There was also a small population of $\mathrm{NCR}^{+}$ILC3s (3\%) identified (27). For both the LTi cells and NCR+ ILC3s there was no disparity in the expression of surface markers compared to cells from the gut. All three populations of RORyt ${ }^{+}$ILCs also expressed chemokine receptor 6 (CCR6).

\section{Discussion}

Neutrophils play an essential role in the innate immune response during infection and inflammation; and their infiltration into the airspace is a hallmark feature of ARDS (1). It has been suggested that the proinflammatory cytokine IL-17A plays a role in neutrophil recruitment within the lung during lung injury (6-8). Utilising an IL-17 KO mouse model (28), the pivotal role of IL-17A in early neutrophil recruitment into the lung following LPS exposure was confirmed.

During lung injury the IL-17 KO mice also showed reduced levels of damage using a number of the criteria set out by Matute-Bello et al (23). There was also abrogation of IL-6 production, a surrogate marker of disease severity in murine models $(29,30)$. MIP-2 is a potent neutrophil chemoattractant and has previously been shown to play a key role in ARDS (31). Expression of MIP-2 is known to be driven by IL-17 via the MAPK pathway (11), offering an insight into the mechanism by which IL-17 is able to exert it's effects during early immunopathogenesis of lung injury. Similar results were observed when lung injury was induced with a clinically relevant bacterial pneumonia model. There was a significant reduction in the percentage of neutrophils detected within the BAL of the IL-17 KO mice, and reduced MIP-2 levels. This is consistent 
with findings using the caecal ligation puncture (CLP) model of polymicrobial sepsis, where IL-17 neutralisation led to a decrease in pro-inflammatory cytokines (TNFa, IL$1 \beta$ and IL-6); and surprisingly, a decrease in bacteraemia (32). This suggests that IL17 neutralisation may have therapeutic potential for the treatment of ARDS, particularly given anti-IL-17 therapy has shown efficacious in experimental models of sepsis (33).

It has been purported that the source of IL-17A in ARDS is $\mathrm{CD4}^{+} \mathrm{T}$ cells; however there is lack of detailed analysis of the specific cellular source. Differentiation of lymphocytes towards a type 17 programme is dependent on the expression of the master regulator transcription factor RORyt (14). Therefore, we phenotyped cells expressing the transcription factor RORyt within the mouse lung during the early phase of lung injury. It was demonstrated that ILCs represented the largest proportions of RORyt ${ }^{+}$cells within the lung during the early pathogenesis. Whilst both $\mathrm{CD}^{+}$and $\mathrm{CD}^{+} \alpha \beta$ T express RORyt, CD8 ${ }^{+}$cells did not produce IL-17A upon exvivo restimulation. This suggests that although predisposed to producing IL-17, Tc17s do not specifically produce IL-17A in this model. It has previously been suggested that, in the presence of Th17 cells, Tc17 cells have reduced functionality due to IL-2 released by $\mathrm{CD}^{+}{ }^{+} \mathrm{T}$ cells (34). This may explain the observation that Tc17 cells contribute little to IL-17 production in this setting.

It was shown that ILC3s were the predominant IL-17A producing cells in the lung during LPS induced lung injury. This conclusion was based on the detection of significantly higher absolute numbers of RORyt ${ }^{+}$plLC3s compared to CD4 ${ }^{+} \mathrm{T}$ cells, but no difference in the median fluorescence intensity, an estimation of the levels of 
IL-17A expression per cell, in CD4 ${ }^{+} \mathrm{T}$ cells and ILC3s. To further verify the critical role of ILCs in lung injury, we examined the relative expression of IL-17 using quantitative real-time PCR. Although there was a reduction in the relative expression in the Rag2 KO mice, which lack T cells, it was only when ILCs were also absent (cy Rag2 DKO) that a significant reduction compared to the WT animals was observed. The proposal of ILC3s as the main source of IL-17A is corroborated by previous studies which have demonstrated that IL-17- induced neutrophil infiltration occurs in SCID mice lacking T cells (6) and the majority of $\mathrm{IL}_{-1}-17^{+}$cells within the BAL are $\mathrm{CD}^{-}$ $(8,9)$. This is mirrored in the oral mucosa, where ILC3s have been shown to be the predominant source of IL-17 in response to Candida infection (35). There were significantly higher numbers of neutrophils and KC levels detected in the lungs of Rag2 KO mice compared to WT controls. This may indicate that the ILC3 cells are normally restrained by Tregs or Bregs, both of which are absent in the Rag2 KO mice. Whilst ILCs predominated the early response during acute lung injury, this appears to be supersede at later time points by an adaptive $\alpha \beta$ T cell response (36).

ILCs are known to be dependent on the common- receptor $y$ chain of the IL-2 family of cytokines for their development (17) and require signalling through the IL-7 receptor subunit alpha (IL-7Ra) (18). Additionally, IL-23 has also been shown to direct and maintain IL-17 production in ILCs (26). Investigation of the role of these cytokines in IL-17A production by ILC3 from LPS primed lungs demonstrated that there is little involvement of IL-7 in this model, despite these cells expressing high levels of IL-7Ra (CD127). In contrast, IL-23 was shown to drive IL-17A production and this was significantly increased by IL-2. This IL-2 augmentation of IL-17A levels could be seen as counter intuitive, given reports that IL-2 inhibits Th17 differentiation 
(37). However, cytokines are known to have a differential effect on developing versus committed Th17 cells (38), and there have been reports of IL-2 expansion of differentiated Th17 cells (39). Furthermore, IL-2 enhances IL-33 driven IL-9 production in ILC2 cells (40). Incubation with IL-2 increased the percentage of ILC3s expressing IL-23 receptor. During the induction of lung injury there was an early peak of IL-2 detected in the murine BAL, presumably this primes the cells for optimal response to IL-23 and subsequent IL-17 production. Whilst the synergistic effects of IL-6, IL-23 and low concentrations of TGF- $\beta$ on the expression of IL-23 receptor have been characterised (41), its upregulation by IL-2 has not been previously described.

A uniform nomenclature has been proposed in order to clarify ILC populations based on phenotypical and functional characteristics (19). The group 3 ILCs produce IL17A, with LTi cells being the prototypical cells in this group (26). Other distinct subsets have been characterised, those expressing the natural killer cell receptor (NCR) NKp46 are denoted $\mathrm{NCR}^{+}$ILC3s and there is also a population that lack NCR, like LTi cells, but are CD4 (19). We examined the expression of a number of cell markers that have previously been used to define ILC populations. Within the lung the ILCs identified were largely comparable to those previously defined in the gut (27, 42). However, there was some variance in the expression of surface markers; therefore we have termed the unique population identified within the inflamed lung as pulmonary ILC3s (pILC3s).

In T cells, the expression of CCR6 is limited to Th17 and Treg cells (43). ILC3s in the gut have been shown to express CCR6 (44). We have demonstrated that pILC3s 
within the lung also expressed CCR6, it therefore seems likely that, as with T cells, CCR6 mediates homing of RORyt ${ }^{+}$ILC3s into tissues and inflammatory sites (43).

Previous studies have demonstrated that ILC2s interact with the lung epithelium and are involved in both repair and pathogenesis (45-47). In contrast, ILC3s had previously only been described playing a protective role in the lung. They function in the repair of the lung following influenza A infection (48) and protect against secondary bacterial infection (49). To the best of our knowledge, this is the first report of ILC3s driving inflammation within the lung and it is clear that an inappropriate response is capable of resulting in immunopathology in the lung, as has been previously described in the gut (12).

In conclusion, the significant decrease in neutrophil infiltration in IL-17KO mice in an LPS-induced model of lung injury confirms the previously surmised key role of this cytokine in the early immunopathogenesis. Most notably, it was demonstrated that the predominant source of this proinflammatory cytokine during lung injury was the innate immune system. Recognition of the role of plLC3s in initiating acute lung inflammation may offer new therapeutic opportunities as modulation of ILCs' function may allow early control of inflammatory dysregulation. 


\section{Acknowledgements}

The authors would like to thank Dr Yoichiro Iwakura (IL-17 KO mice), Dr Mark Wilson

(Rag2 KO and $\mathrm{c} \gamma$ Rag2 DKO mice) and Prof Scott Bell (PA01 P. aeruginosa) for kindly providing resources utilised within this study.

\section{Disclosure}

Drs. Muir \& Osbourn reports other from Department of Education and Learning (Northern Ireland), during the conduct of the study. Dr. McAuley reports personal fees from GlaxoSmithKline, personal fees from Peptinnovate, outside the submitted work; In addition, Dr. McAuley has a patent application pending to Queen's University Belfast. Dr. Ingram reports grants from Queen's University Belfast, during the conduct of the study. 


\section{References}

1. Ware LB, Matthay MA. The acute respiratory distress syndrome. N Eng/ J Med 2000;342:1334-49.

2. Whitney CG, Farley MM, Hadler J, Harrison LH, Bennett NM, Lynfield R, Reingold A, Cieslak PR, Pilishvili T, Jackson D, Facklam RR, Jorgensen JH, Schuchat A. Decline in invasive pneumococcal disease after the introduction of protein-polysaccharide conjugate vaccine. N Engl J Med 2003;348:1737-46.

3. Harris JF, Aden J, Lyons CR, Tesfaigzi Y. Resolution of LPS-induced airway inflammation and goblet cell hyperplasia is independent of IL-18. Respir Res 2007;8:24.

4. Morris PE, Glass J, Cross R, Cohen DA. Role of T-lymphocytes in the resolution of endotoxin-induced lung injury. Inflammation 1997;21:269-78.

5. Nakajima T, Suarez CJ, Lin K-W, Jen KY, Schnitzer JE, Makani SS, Parker N, Perkins DL, Finn PW. T cell pathways involving CTLA4 contribute to a model of acute lung injury. J Immunol 2010;184:5835-41.

6. Ferretti S, Bonneau O, Dubois GR, Jones CE, Trifilieff A. IL-17, produced by lymphocytes and neutrophils, is necessary for lipopolysaccharide-induced airway neutrophilia: IL-15 as a possible trigger. J Immunol 2003;170:2106-12.

7. Anthony D, Seow HJ, Uddin M, Thompson M, Dousha L, Vlahos R, Irving LB, Levy BD, Anderson GP, Bozinovski S. Serum amyloid A promotes lung neutrophilia by increasing IL-17A levels in the mucosa and $ү \delta \mathrm{T}$ cells. $A m \mathrm{~J}$ Respir Crit Care Med 2013;188:179-86.

8. Miyamoto M, Prause O, Sjöstrand M, Laan M, Lötvall J, Lindén A. Endogenous $\mathrm{IL}-17$ as a mediator of neutrophil recruitment caused by endotoxin exposure in mouse airways. J Immunol 2003;170:4665-72.

9. Prause O, Bossios A, Silverpil E, Ivanov S, Bozinovski S, Vlahos R, Sjöstrand M, Anderson GP, Lindén A. IL-17-producing T lymphocytes in lung tissue and in the bronchoalveolar space after exposure to endotoxin from Escherichia coli in vivo--effects of anti-inflammatory pharmacotherapy. Pulm Pharmacol Ther 2009;22:199-207.

10. Gaffen SL. Recent advances in the IL-17 cytokine family. Curr Opin Immunol 2011;23:613-9.

11. Iyoda M, Shibata T, Kawaguchi M, Hizawa N, Yamaoka T, Kokubu F, Akizawa T. IL-17A and IL-17F stimulate chemokines via MAPK pathways (ERK1/2 and p38 but not JNK) in mouse cultured mesangial cells: synergy with TNF-alpha and IL-1beta. Am J Physiol Renal Physiol 2010;298:F779-87. 
12. Buonocore S, Ahern PP, Uhlig HH, Ivanov II, Littman DR, Maloy KJ, Powrie F. Innate lymphoid cells drive interleukin-23-dependent innate intestinal pathology. Nature 2010;464:1371-5.

13. Ivanov II, McKenzie BS, Zhou L, Tadokoro CE, Lepelley A, Lafaille JJ, Cua DJ, Littman DR. The orphan nuclear receptor RORgammat directs the differentiation program of proinflammatory $\mathrm{IL}-17+\mathrm{T}$ helper cells. Cell 2006;126:1121-33.

14. Hirota $\mathrm{K}$, Ahlfors $\mathrm{H}$, Duarte JH, Stockinger B. Regulation and function of innate and adaptive interleukin-17-producing cells. EMBO Rep 2012;13:113-20.

15. Cua DJ, Tato CM. Innate IL-17-producing cells: the sentinels of the immune system. Nat Rev Immunol 2010;10:479-89.

16. Tait Wojno ED, Artis D. Innate lymphoid cells: balancing immunity, inflammation, and tissue repair in the intestine. Cell Host Microbe 2012;12:445-57.

17. Spits $\mathrm{H}$, Cupedo $\mathrm{T}$. Innate lymphoid cells: emerging insights in development, lineage relationships, and function. Annu Rev Immunol 2012;30:647-75.

18. Vonarbourg C, Diefenbach A. Multifaceted roles of interleukin-7 signaling for the development and function of innate lymphoid cells. Semin Immunol 2012;24:165-74.

19. Spits H, Artis D, Colonna M, Diefenbach A, Di Santo JP, Eberl G, Koyasu S, Locksley RM, McKenzie ANJ, Mebius RE, Powrie F, Vivier E. Innate lymphoid cells - a proposal for uniform nomenclature. Nat Rev Immunol 2013;13:145-9.

20. Muir R, Cross M, O'Kane C, Craig T, Shyamsundar M, McAuley D, Ingram R. S59 The Role of Lymphocytes in Acute Lung Injury. Thorax 2012;67:A30-A30.

21. Muir R, McAuley D, Ingram R. The role of Tregs in controlling IL-17A in a model of LPS-induced lung injury. Eur Respir J 2012;40:P836-.

22. Roshell R. Muir, Daniel F. McAuley and RJI. Innate Lymphoid Cells Are The Predominant Producers Of IL-17A Which Is Important For Neutrophil Recruitment In Acute Lung Injury (ATS Journals). Am J Respir Crit Care Med 2013;187:A4917.

23. Matute-Bello G, Downey G, Moore BB, Groshong SD, Matthay MA, Slutsky AS, Kuebler WM. An official American Thoracic Society workshop report: features and measurements of experimental acute lung injury in animals. Am J Respir Cell Mol Biol 2011;44:725-38.

24. Pfaffl MW. A new mathematical model for relative quantification in real-time RT-PCR. Nucleic Acids Res 2001;29:e45. 
25. Mullane KM, Kraemer R, Smith B. Myeloperoxidase activity as a quantitative assessment of neutrophil infiltration into ischemic myocardium. $J$ Pharmacol Methods 1985;14:157-67.

26. Takatori H, Kanno Y, Watford WT, Tato CM, Weiss G, Ivanov II, Littman DR, O'Shea JJ. Lymphoid tissue inducer-like cells are an innate source of IL-17 and IL-22. J Exp Med 2009;206:35-41.

27. Satoh-Takayama N, Vosshenrich CAJ, Lesjean-Pottier S, Sawa S, Lochner M, Rattis F, Mention J-J, Thiam K, Cerf-Bensussan N, Mandelboim O, Eberl G, Di Santo JP. Microbial flora drives interleukin 22 production in intestinal NKp46+ cells that provide innate mucosal immune defense. Immunity 2008;29:958-70.

28. Nakae S, Komiyama Y, Nambu A, Sudo K, Iwase M, Homma I, Sekikawa K, Asano M, Iwakura Y. Antigen-specific T cell sensitization is impaired in IL-17deficient mice, causing suppression of allergic cellular and humoral responses. Immunity 2002;17:375-87.

29. Ingram RJ, Isaacs JD, Kaur G, Lowther DE, Reynolds CJ, Boyton RJ, Collinge $J$, Jackson GS, Altmann DM. A role of cellular prion protein in programming Tcell cytokine responses in disease. FASEB J 2009;23:1672-84.

30. Zhang H, Neuhöfer P, Song L, Rabe B, Lesina M, Kurkowski MU, Treiber M, Wartmann T, Regnér S, Thorlacius H, Saur D, Weirich G, Yoshimura A, Halangk W, Mizgerd JP, Schmid RM, Rose-John S, Algül H. IL-6 transsignaling promotes pancreatitis-associated lung injury and lethality. J Clin Invest 2013;123:1019-31.

31. Tsujimoto H, Ono S, Mochizuki H, Aosasa S, Majima T, Ueno C, Matsumoto A. Role of macrophage inflammatory protein 2 in acute lung injury in murine peritonitis. J Surg Res 2002;103:61-7.

32. Bosmann M, Ward PA. Therapeutic potential of targeting IL-17 and IL-23 in sepsis. Clin Transl Med 2012;1:4.

33. Li J, Zhang Y, Lou J, Zhu J, He M, Deng X, Cai Z. Neutralisation of peritoneal IL-17A markedly improves the prognosis of severe septic mice by decreasing neutrophil infiltration and proinflammatory cytokines. In: Ryffel B, editor. PLOS One 2012;7:e46506.

34. Tsai J-P, Lee M-H, Hsu S-C, Chen M-Y, Liu S-J, Chang JT, Liao C-T, Cheng A-J, Chong P, Chu C-L, Shen C-R, Chen H-W. CD4+ T cells disarm or delete cytotoxic T lymphocytes under IL-17-polarizing conditions. J Immunol 2012;189:1671-9.

35. Gladiator A, Wangler N, Trautwein-Weidner K, LeibundGut-Landmann S. Cutting edge: IL-17-secreting innate lymphoid cells are essential for host defense against fungal infection. $J$ Immunol 2013;190:521-5. 
36. Li JT, Melton AC, Su G, Hamm DE, LaFemina M, Howard J, Fang X, Bhat S, Huynh K-M, O'Kane CM, Ingram RJ, Muir RR, McAuley DF, Matthay MA, Sheppard D. Unexpected Role for Adaptive Th17 Cells in Acute Respiratory Distress Syndrome. J Immunol 2015;195:87-95.

37. Laurence A, Tato CM, Davidson TS, Kanno Y, Chen Z, Yao Z, Blank RB, Meylan F, Siegel R, Hennighausen L, Shevach EM, O'shea JJ. Interleukin-2 signaling via STAT5 constrains $\mathrm{T}$ helper 17 cell generation. Immunity 2007;26:371-81.

38. El-behi M, Ciric B, Yu S, Zhang G-X, Fitzgerald DC, Rostami A. Differential effect of IL-27 on developing versus committed Th17 cells. J Immunol 2009;183:4957-67.

39. Amadi-Obi A, Yu C-R, Liu X, Mahdi RM, Clarke GL, Nussenblatt RB, Gery I, Lee YS, Egwuagu CE. TH17 cells contribute to uveitis and scleritis and are expanded by IL-2 and inhibited by IL-27/STAT1. Nat Med 2007;13:711-8.

40. Wilhelm C, Stockinger B. Innate lymphoid cells and type 2 (th2) mediated immune responses - pathogenic or beneficial? Front Immunol 2011;2:68.

41. Zhou L, Lopes JE, Chong MMW, Ivanov II, Min R, Victora GD, Shen Y, Du J, Rubtsov YP, Rudensky AY, Ziegler SF, Littman DR. TGF-beta-induced Foxp3 inhibits $\mathrm{T}(\mathrm{H}) 17$ cell differentiation by antagonizing RORgammat function. Nature 2008;453:236-40.

42. Luci C, Reynders A, Ivanov II, Cognet C, Chiche L, Chasson L, Hardwigsen J, Anguiano E, Banchereau J, Chaussabel D, Dalod M, Littman DR, Vivier E, Tomasello E. Influence of the transcription factor RORgammat on the development of NKp46+ cell populations in gut and skin. Nat Immunol 2009;10:75-82.

43. Wang C, Kang SG, Lee J, Sun Z, Kim CH. The roles of CCR6 in migration of Th17 cells and regulation of effector T-cell balance in the gut. Mucosal Immunol 2009;2:173-83.

44. Geremia A, Arancibia-Cárcamo C V, Fleming MPP, Rust N, Singh B, Mortensen NJ, Travis SPL, Powrie F. IL-23-responsive innate lymphoid cells are increased in inflammatory bowel disease. J Exp Med 2011;208:1127-33.

45. Halim TYF, Krauss RH, Sun AC, Takei F. Lung natural helper cells are a critical source of Th2 cell-type cytokines in protease allergen-induced airway inflammation. Immunity 2012;36:451-63.

46. Hams E, Armstrong ME, Barlow JL, Saunders SP, Schwartz C, Cooke G, Fahy RJ, Crotty TB, Hirani N, Flynn RJ, Voehringer D, McKenzie ANJ, Donnelly SC, Fallon PG. IL-25 and type 2 innate lymphoid cells induce pulmonary fibrosis. Proc Natl Acad Sci U S A 2014;111:367-72. 
47. Chang Y-J, Kim HY, Albacker LA, Baumgarth N, McKenzie ANJ, Smith DE, Dekruyff RH, Umetsu DT. Innate lymphoid cells mediate influenza-induced airway hyper-reactivity independently of adaptive immunity. Nat Immunol 2011;12:631-8.

48. Monticelli LA, Sonnenberg GF, Abt MC, Alenghat T, Ziegler CGK, Doering TA, Angelosanto JM, Laidlaw BJ, Yang CY, Sathaliyawala T, Kubota M, Turner D, Diamond JM, Goldrath AW, Farber DL, Collman RG, Wherry EJ, Artis D. Innate lymphoid cells promote lung-tissue homeostasis after infection with influenza virus. Nat Immunol 2011;12:1045-54.

49. Ivanov S, Renneson J, Fontaine J, Barthelemy A, Paget C, Macho Fernandez E, Blanc F, De Trez C, Van Maele L, Dumoutier L, Huerre M-R, Eberl G, SiTahar M, Gosset P, Renauld JC, Sirard JC, Faveeuw C, Trottein F. Interleukin22 reduces lung inflammation during influenza $A$ virus infection and protects against secondary bacterial infection. J Virol 2013;doi:10.1128/JVI.02943-12. 


\section{Legends}

TABLE 1. Phenotypic markers of lung innate lymphoid cells. Lin ${ }^{-} C D 45^{+} \mathrm{RORyt}^{+}$ lung ILC3s were analysed by flow cytometry and the expression of cell surface markers associated with ILC subsets were characterised (Figure E2); 3 discrete populations were identified. The data is representative of three independent experiments, each experiment utilised $n=3$ mice pooled. LTi, lymphoid tissue inducer cell; NCR, natural cytotoxicity receptor; SCA-1, stem cell antigen-1; NK, natural killer.

FIGURE 1. IL-17 plays a key role in the recruitment of neutrophils during the early pathogenesis of LPS induced lung injury. Following (24 h) LPS administration there was a difference in the levels of injury detected within the lungs of WT C57BL/6 or IL-17KO mice. Representative images from H\&E stained lungs ( $\mathrm{x}$ 20 magnification) are shown (A) along with scoring based on neutrophils in the alveolar space, neutrophils in the interstitial space, hyaline membranes, proteinaceous debris filling the airspaces and alveolar septal thickening (23) ( $n=3$ mice per treatment) (B). The lung index (Lung index = (lung weight/body weight experimental) / (lung weight/body weight control)), indicative of pulmonary inflammation, was calculated ( $n=6$ per group) (C). BAL was collected and the levels of protein detected ( $n=18-20$ per group) (D). Neutrophils $\left(L y 6-G^{+}\right.$CD11 $\left.b^{+}\right)$were analysed by flow cytometry and the absolute numbers of BAL neutrophils calculated $(n=6-10$ per group) (E). Levels of MPO activity (F), IL-6 (G) KC (H) and MIP-2 (I) were measured in the BAL fluid ( $n=10-20$ per group). ${ }^{*} p<0.05$. 
FIGURE 2. Reduced neutrophil recruitment is observed in IL-17 KO mice following bacterial pneumonia induced lung injury. WT C57BL/6 or IL-17 KO mice were inoculated intranasally with $5 \times 10^{6} \mathrm{CFUs}$ of Pseudomonas aeruginosa (PA01), BAL was collected $24 \mathrm{~h}$ post inoculation and the percentage of neutrophils $\left(\right.$ Ly6-G ${ }^{+}$CD11 $\left.b^{+}\right)$analysed by flow cytometry (A). Total protein (B), IL-6 (C) and MIP2 (D) levels were quantified ( $n=8$ per strain). ${ }^{*} p<0.05$.

FIGURE 3. RORyt ${ }^{+}$lymphocytes are recruited to the lung of mice during LPSinduced lung injury. Lung cells were harvested $24 \mathrm{~h}$ post LPS administration and flow cytometry was performed. The absolute number of RORyt ${ }^{+}$lung cells was calculated using the total lung cell count and the percentage of RORyt ${ }^{+}$cells $(A)$. The $\mathrm{RORyt}^{+}$cells within the lung were phenotyped and the percentage of NK cells (CD3 NK1. $\left.1^{+}\right)$, NKT cells $\left(\mathrm{CD}^{+} \mathrm{NK} 1.1^{+}\right)$, Th17 cells $\left(\mathrm{CD} 3^{+} \mathrm{NK} 1.1^{-} \mathrm{CD} 4^{+}\right)$, Tc17 cells $\left(\mathrm{CD} 3^{+}\right.$ NK1.1 $\left.1^{-} \mathrm{CD}^{+}\right)$, $\gamma \delta \mathrm{T}$ cells $\left(\gamma \delta \mathrm{TCR}^{+}\right)$and ILCs $\left(\mathrm{CD}^{+} 5^{+} \mathrm{Lin}^{-} \mathrm{NK} 1.1^{-} \gamma \delta \mathrm{TCR}^{-}\right)$ determined (B). The in vivo LPS primed cells were cultured and restimulated to increase IL-17 production, in the presence of a golgi block to prevent cytokine secretion. Intracellular cytokine staining, using either anti-IL-17A or an isotype control was performed. The isotype control, which demonstrates the levels of non-specific binding, was used to position the positive gate and the production of IL-17A in RORyt $^{+}$cells (black) and RORyt cells (grey) was plotted against side scatter (SSC) assessed $(C)$ ( $n=3$ mice pooled, in three independent experiments). ${ }^{*} p<0.05$. 
FIGURE 4. There are significantly more RORyt ${ }^{+}$ILCs than Th17 cells in the lung during the early stages of LPS induced lung injury. LPS, or saline control, was administered o.t to C57BL/6 mice. Lungs were harvested after $24 \mathrm{~h}$ and flow cytometry performed. LPS administration resulted in a significant increase in the absolute numbers of RORyt ${ }^{+}$ILC3s within the lung (A). Higher numbers of ILC3s than Th17 (CD4+) T cells were detected following LPS administration (B). When these cells were restimulated ex vivo there was no difference in the median fluorescent intensity (MFI), an indication of the amount of expression per cell, of IL17A expression between ILC3s and Th17 cells (C) ( $n=3$ mice/group pooled, three independent experiments performed). ${ }^{*} p<0.05$.

FIGURE 5. Induction of lung injury in mice lacking $T$ cells, confirms the critical role of ILC in IL-17 production and neutrophil recruitment. The lung of WT, Rag2 KO (lacking T cells) and cy Rag2 DKO (lacking both T cells and ILCs) were harvested $4 \mathrm{~h}$ post LPS exposure. The expression of IL-17A was analysed by realtime PCR; the data were normalised using the house-keeping gene YWHAZ and the $2^{-\Delta \Delta C T}$ used to analyse the expression levels relative to a PBS control (WT and Rag2 KO $n=13$ per strain, cy Rag2 DKO $n=6)(A)$. Lung injury was induced in WT and Rag2 KO mice by i.n administration of LPS; after $24 \mathrm{~h}$ the lungs were harvested and weighed to calculate the lung index (B). The lungs were homogenised and the levels of MIP-2 (C), the total number of neutrophils (D), IL-6 (E), and KC (F) concentration calculated $\left(n=6\right.$ per strain) $.^{*} p<0.05$. 
FIGURE 6. IL-23 induces IL-17A production in lung lymphocytes which is amplified in the presence of IL-2. Cells harvested from the lungs of LPS treated mice were incubated ex vivo with rIL-23, rIL-2 and rIL-7 or combinations of these cytokines. The cell culture supernatants were sampled at $4,24,48,72 \mathrm{~h}$ and the level of IL-17A quantified (A) ( $n=3$ mice pooled, 6 replicates). Cells were cultured with all possible combinations of cytokines for $72 \mathrm{~h}$ and the levels of IL-17A determined (B) ( $n=3$ mice pooled, repeated 3 times), ${ }^{*} p<0.05 .$. Flow cytometry was used to stain intracellular IL-17A levels following stimulation with IL-2 and IL-23 and to determine the percentage of IL-17 $7^{+}$cells which were ILC3s (C). The percentage of ILC3s expressing IL-23R on their surface following culture with IL-2 was analysed by flow cytometry (D) ( $n=3$ mice pooled, in triplicate). Following the induction of acute lung injury in C57BL/6 mice the levels of IL-23p19 within the BAL at $24 \mathrm{~h}$ was assessed (E) ( $n=10-16 /$ group, $\left.{ }^{*} p<0.05\right)$, IL-2 levels in the BAL were quantified at 8 , 12 and $24 \mathrm{~h}$ post LPS exposure (F) (LPS $\mathrm{n}=4$ per time point, PBS $\mathrm{n}=3$ per time point, $\left.{ }^{*} p<0.05\right)$. 
TABLE 1

\begin{tabular}{|c|c|c|c|}
\hline $\begin{array}{l}\text { ILC Group } 3 \\
\text { subset }\end{array}$ & plLC3 & $\begin{array}{l}\text { LTi } \\
\text { cells }\end{array}$ & $\begin{array}{l}\mathrm{NCR}^{+} \\
\mathrm{ILC3}\end{array}$ \\
\hline \multicolumn{4}{|l|}{ Marker } \\
\hline Lin $^{-} \mathrm{CD}{ }^{+}{ }^{+} \mathrm{RORyt}^{+}$ & + & + & + \\
\hline CD90 (Thy1) & + & + & + \\
\hline Sca1 (Ly6A) & + & - & - \\
\hline NKp46 (NCR) & - & - & + \\
\hline CD117 (c-Kit) & + & + & + \\
\hline CD127 (IL-7Ra) & + & + & + \\
\hline CD4 & - & high & low \\
\hline CCR6 & + & + & + \\
\hline $\begin{array}{l}\text { Percentage } \\
\text { detected }\end{array}$ & 58 & 21 & 3 \\
\hline Reference & $\begin{array}{l}\text { This } \\
\text { study }\end{array}$ & $(19,24)$ & $(19,25)$ \\
\hline
\end{tabular}


Figure 1

A

PBS

LPS

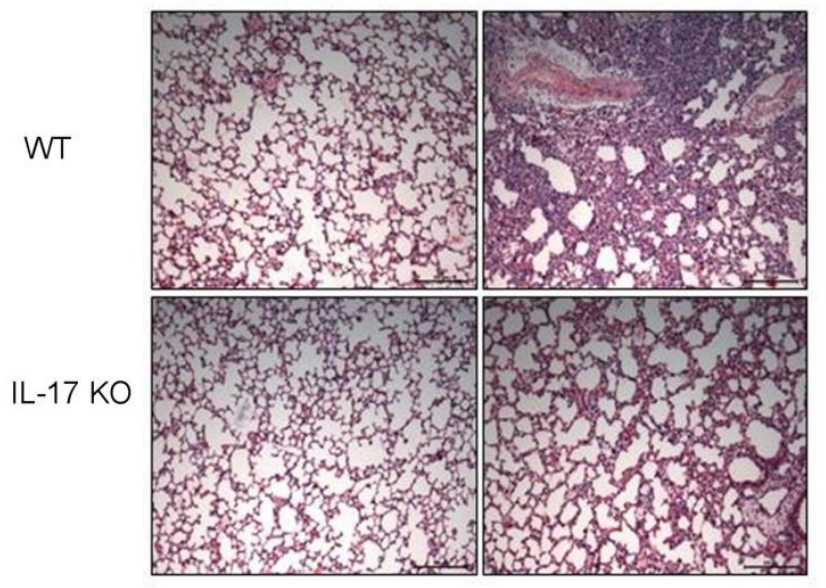

D

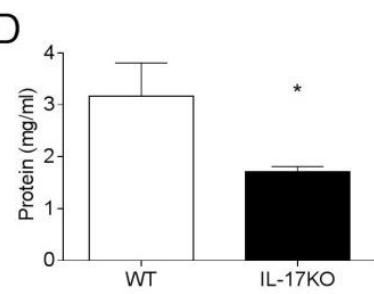

E
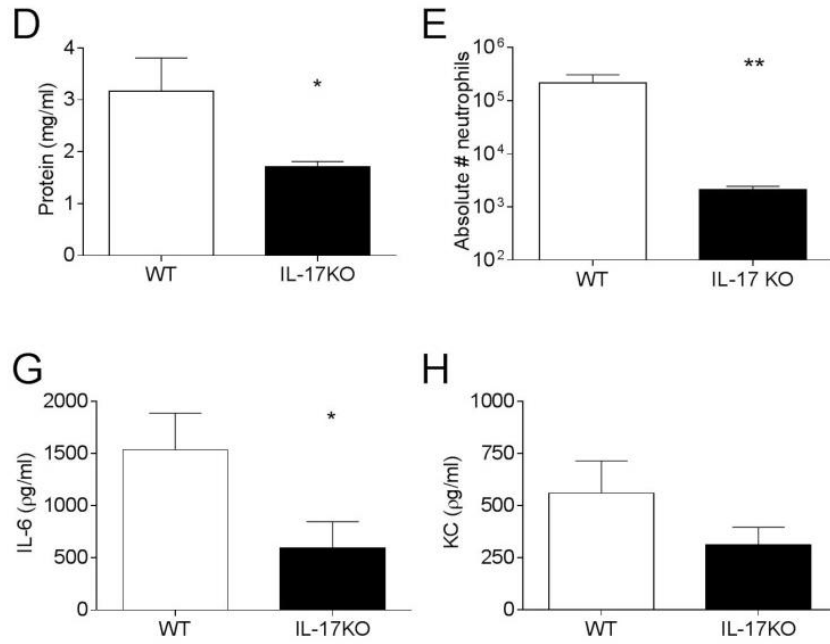

$\mathrm{H}$

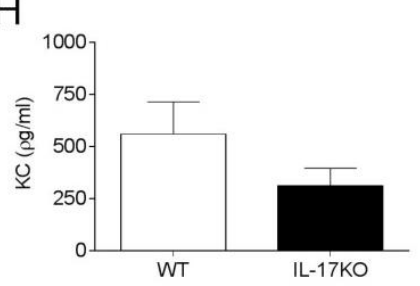

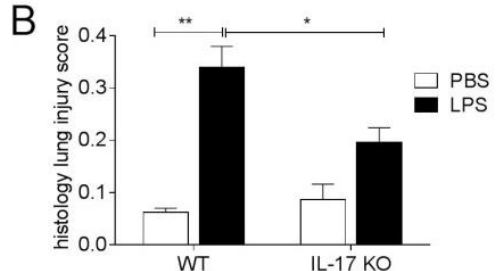

C

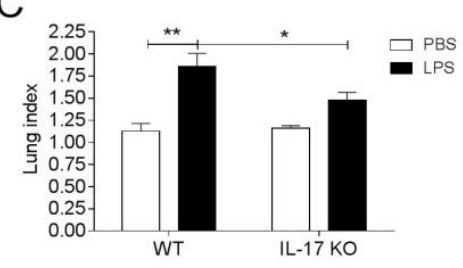

F

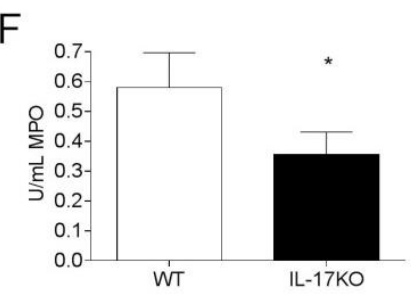

I

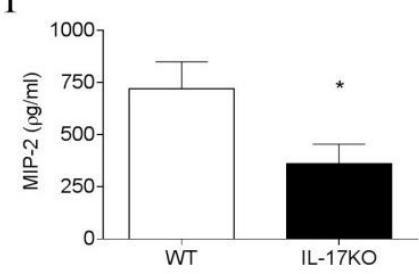


Figure 2

A

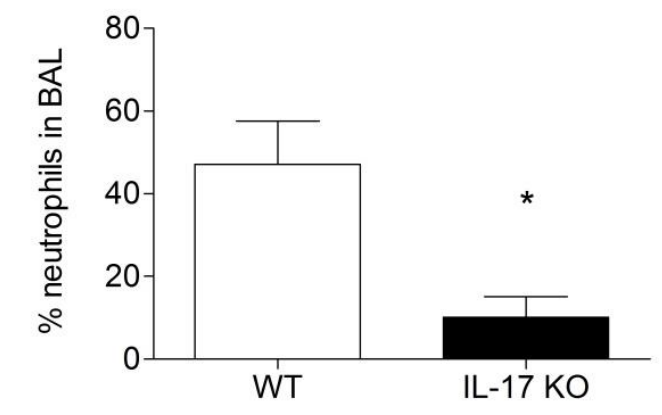

C

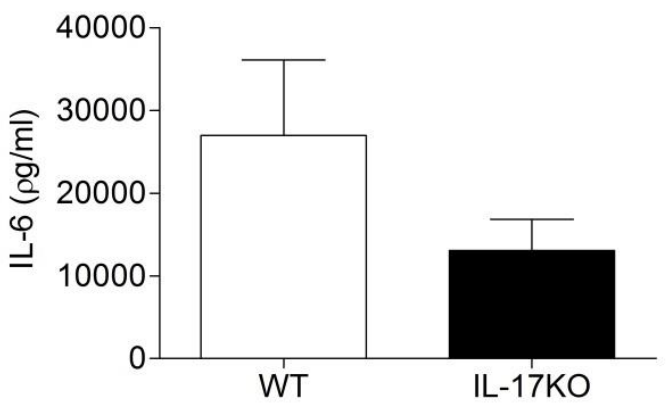

B

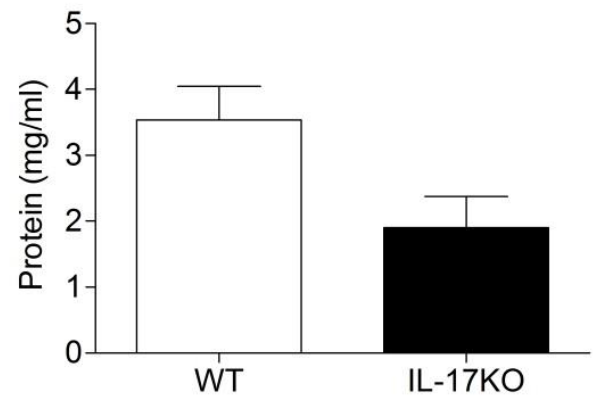

D

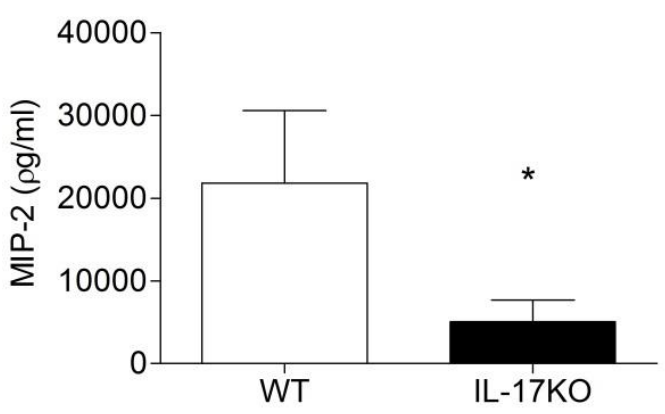


Figure 3

A

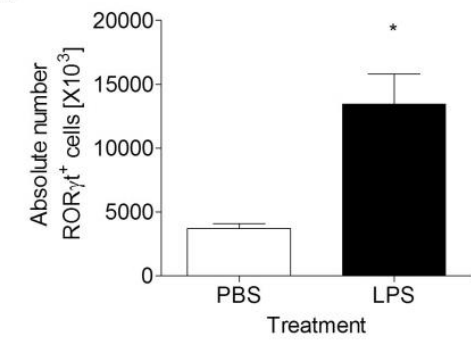

B

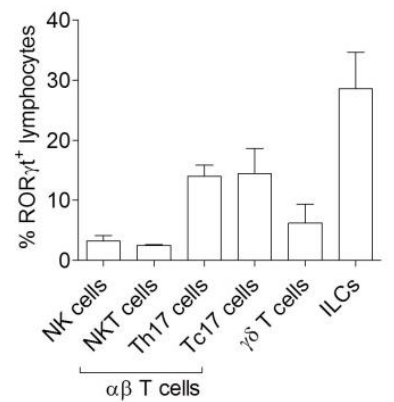

C

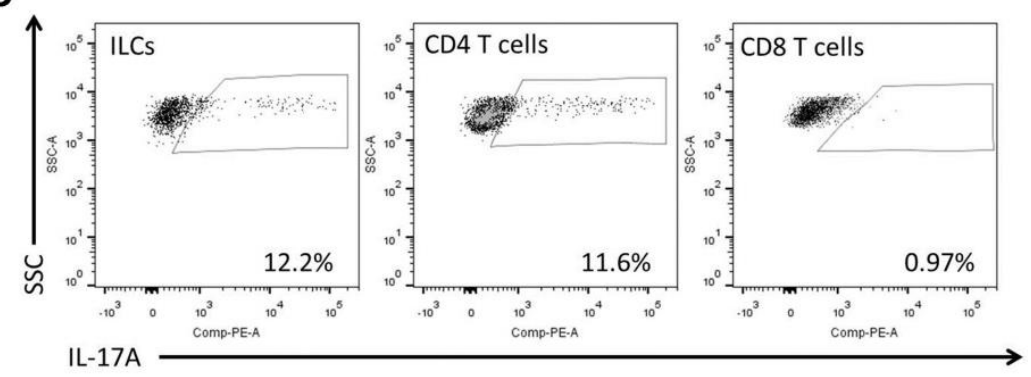

Figure 4

A

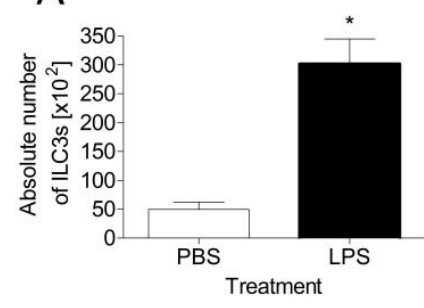

B

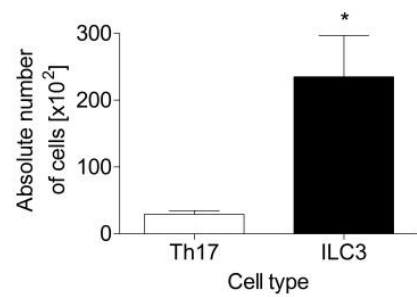

C

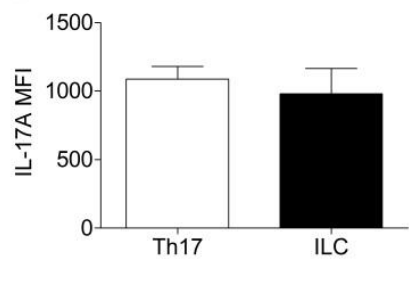


Figure 5

A

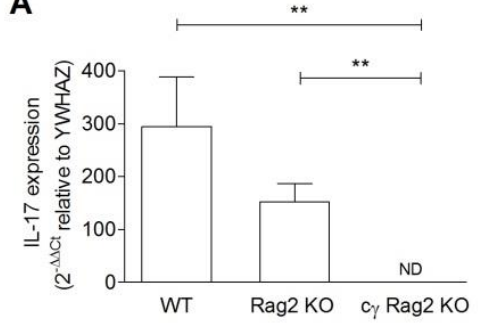

D

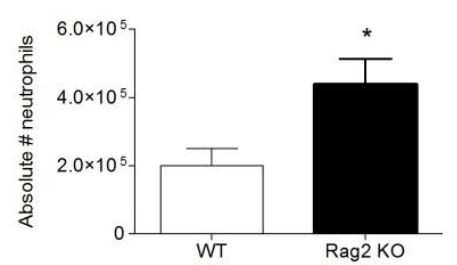

B

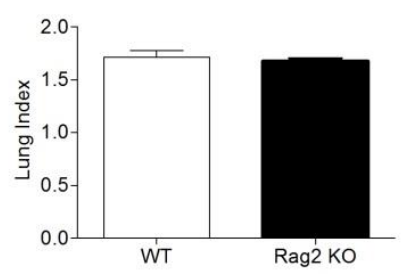

E

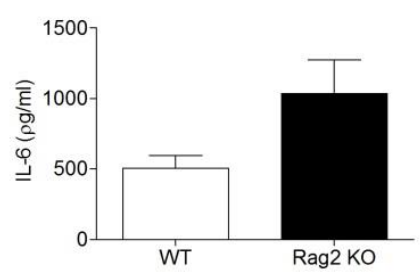

C

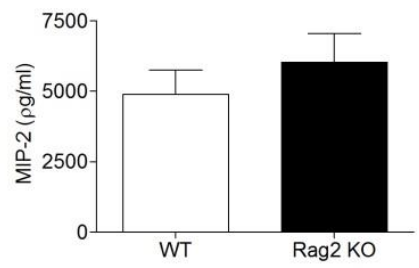

F

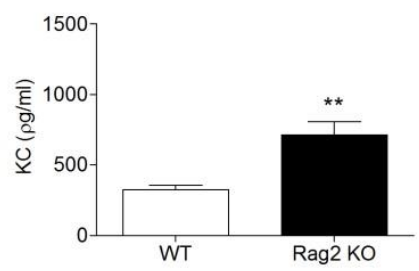

Figure 6

A

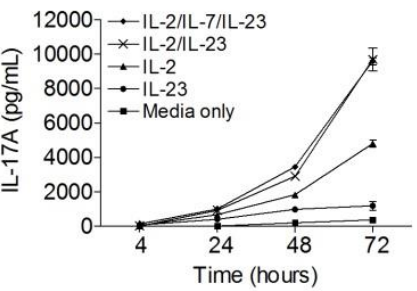

D

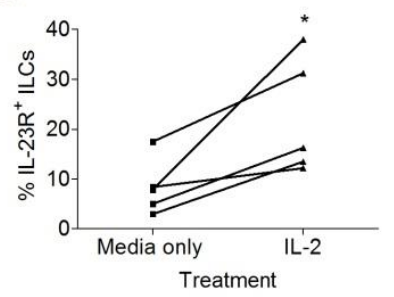

B

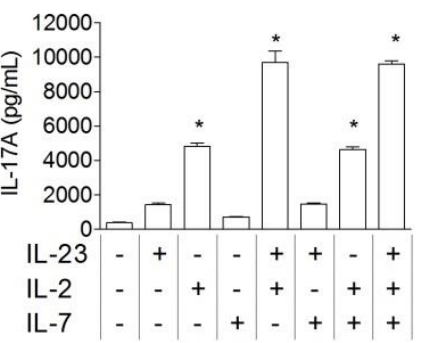

E

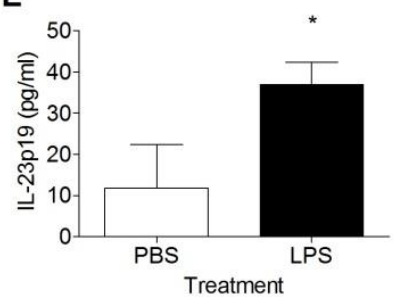

C

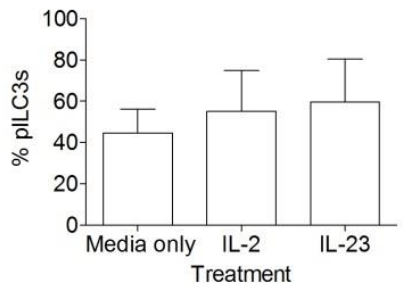

G

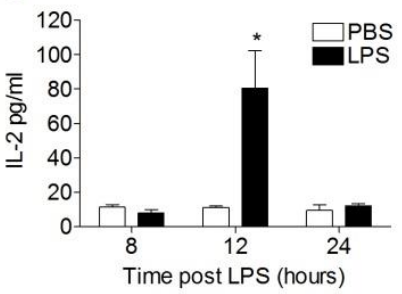


Online Data Supplement

Innate lymphoid cells are the predominant source of interleukin-17A during the early pathogenesis of acute respiratory distress syndrome

Roshell Muir $^{1 \dagger}$, Megan Osbourn ${ }^{1 \dagger}$, Alice V. Dubois ${ }^{1}$, Emma Doran ${ }^{1}$, Donna M. Small ${ }^{1}$, Avril Monahan ${ }^{1}$, Cecilia M. O’Kane ${ }^{1}$, Katherine McAllister ${ }^{1}$, Denise C. Fitzgerald ${ }^{1}$, Adrien Kissenpfennig ${ }^{1}$, Daniel F. McAuley ${ }^{1,2}$, and Rebecca J. Ingram ${ }^{1 *}$. 


\section{Supplementary Methods}

Mice

All studies were approved by Queen's University Belfast's ethical committee and were conducted in accordance with the UK Home Office regulations. Sex- and age(6-14 weeks) matched C57BL/6 wild-type (WT) mice and IL-17A KO mice (kindly provided by Dr Yoichiro Iwakura, Institute of Medical Science, The University of Tokyo, Japan) (1) were bred in house. Recombinase activating gene 2-deficient (Rag2 KO) mice (2) on C57BL/6 background and mice deficient in both Rag2 and the common cytokine receptor y chain (cy Rag2 DKO) (3) on a Balb/c background were kindly provided by Dr Mark Wilson, MRC National Institute for Medical Research, UK. Rag2 KO lack T cells but retain ILCs, in contrast cy Rag2 DKO lack both T cell and ILCs.

Induction of lung injury in mice.

Lung injury was induced in mice by the administration of either E. coli LPS $(100 \mu \mathrm{g})$ (Sigma, UK- serotype 0111:B4) suspended in injection grade saline, or inoculation with $5 \times 10^{6}$ CFUs of Pseudomonas aeruginosa (PA01, kindly provided by Prof Scott Bell, Australian Infectious Diseases Research Centre). This clinically relevant bacterial pneumonia model was chosen as it induces significant levels of lung injury (4). In contrast, in the widely used CLP model, it has recently been demonstrated that lung injury is not the primary cause of mortality in the mice (5).

Mice were anaesthetised with xylazine and ketamine by intraperitoneal (i.p.) injection. Unless otherwise stated, all mice were administered LPS via the orotracheally (o.t) route. Mice were intubated using a high-pressure syringe and MicroSprayer 
aerosoliser (Penn-Century. Inc. Wyndmoor, PA) (6). LPS or a saline control were delivered into the lung $(50 \mu \mathrm{l})$. For intra-nasal (i.n) administration, $20 \mu \mathrm{l}$ of LPS, bacteria or a saline control were applied drop wise to the animal's nose, these were inhaled by normal respiration. Following i.n administration, animals became tachypneic, they were held in an upright position until their breathing normalised to ensure maximal delivery into the lungs. Mice were culled at $24 \mathrm{~h}$ post induction, unless otherwise stated. To calculate the lung indice, a measure of pulmonary inflammation (7), the following equation was used;

Lung index $=\quad$ lung weight/body weight experimental lung weight/body weight control

\section{Lung Histology}

Lungs were excised and fixed in $10 \%$ formaldehyde over night at room temperature for histological processing. Lung tissue was embedded in paraffin by members of the core tissue unit (CTU) in QUB and $3 \mu \mathrm{m}$ sections were sectioned and floated onto a saline coated slide (MSC, Ireland) and dried in an oven at $60^{\circ} \mathrm{C}$. The sections were de-waxed with Histoclear (National Diagnostics, US), rehydrated in decreasing concentrations of alcohol, before final transfer to distilled water for 5 minutes. Sections were stained with Haematoxylin and eosin (H\&E), dried then mounted using DPX mounting media (HD Supplies, UK) and cover slips applied. DPX was allowed to solidify overnight and sections were then examined microscopically. A researcher blinded to the mouse strain/treatment group of each scored the damage to the lung in $\geq 5$ field of view for each section using the system outlined by Matute-Bello et al (8). 
Quantification of inflammatory markers within the lung.

BAL was obtained by the instillation of four successive $150 \mu \mathrm{L}$ aliquots of ice cold sterile PBS into the mouse lung and the recovered fluid from each wash was pooled for each individual animal. Samples were stored on ice until cell-free supernatant was obtained by centrifugation $\left(300 \times \mathrm{g}, 10\right.$ minutes, $\left.4^{\circ} \mathrm{C}\right)$. For the preparation of lung homogenate, lungs were harvested and stored on ice. They were homogenised in $500 \mu \mathrm{l}$ of sterile, ice cold PBS with a mechanical homogeniser (VWR, UK). The sample was then gently centrifuged $\left(300 \times \mathrm{g}, 10\right.$ minutes, $\left.4^{\circ} \mathrm{C}\right)$ to pellet the cellular material and the supernatant was collected. All samples were stored at $-80^{\circ} \mathrm{C}$ until analysed.

ELISA was used to quantify IL-17A, IL-6, IL-23 (eBioscience, UK), keratinocytederived chemokine (KC), MIP-2 (Preprotech, USA); IL-2 was quantified by luminex assay (Invitrogen, UK), all following the manufacturer protocols.

Myeloperoxidase (MPO) activity was measured in the BAL fluid collected from murine in vivo experiments. MPO from human leukocytes was used to generate a standard curve $(0.0625 \mathrm{U} / \mathrm{mL}-0.000977 \mathrm{U} / \mathrm{mL})$. The standards and samples were diluted (1:50) in assay buffer (potassium phosphate dibasic solution $2.5 \mu \mathrm{M})$. The samples were then added to a black 96 -well plate (Sterilin, UK) with $50 \mu \mathrm{L}$ of reaction cocktail (50 $\mathrm{\mu M}$ amplifu red, $20 \mathrm{mM}$ hydrogen peroxide in assay buffer). The plate was incubated at room temperature in the dark for 60 minutes before measuring the fluorescence at excitation 530-570 nm and emission at 590-600 nm. All components were purchased from Sigma, UK. 
Total protein concentration was measured in the BAL fluid against a standard curve of pre-determined bovine serum albumin (BSA) standards ranging from $2 \mathrm{mg} / \mathrm{mL}$ to $31.25 \mu \mathrm{g} / \mathrm{mL}$ (Thermo Scientific, UK) using Pierce BCA protein assay (Thermo Scientific, UK) as stated in the manufacturer's protocol. Assays were read at $450 \mathrm{~nm}$ on a spectrophotometer (BioTek, U.S.A).

\section{Isolation and preparation of lung cells}

Lungs were perfused with cold sterile PBS through the right ventricle of the heart then harvested into Iscoves's Modified Dulbecco's Medium (IMDM) (Gibco, UK) supplemented with $10 \%$ fetal calf serum (FCS) (Source Bioscience, UK) and $1 \%$ penicillin/streptomycin (PAA, UK). To prepare a single-cell suspension, the lung was finely minced and incubated at $37^{\circ} \mathrm{C}$ in media, supplemented with $1 \mathrm{mg} / \mathrm{mL}$ Collagenase D and $200 \mu \mathrm{g} / \mathrm{mL}$ DNase 1 (Roche, Germany), for 1 hour with constant agitation. After incubation, the samples were passed through a $70 \mu \mathrm{m}$ cell strainer (Becton Dickinson, UK), centrifuged ( $300 \times \mathrm{g}, 5$ minutes, RT) and the red blood cells lysed. A live-dead cell count was then performed on the single cell suspension using a Countess automated cell counter (Invitrogen, UK).

\section{Ex vivo cell stimulation}

Single cell suspension prepared from the lungs were plated in IMDM media supplemented with $10 \%$ FCS and $1 \% \mathrm{P} / \mathrm{S}$, and stimulated with IL-23 (50 ng/ml), IL-7 (10 ng/ml) (Milteni, UK) or IL-2 (10 ng/ml) (Dynax, USA) or combinations of these cytokines. The cells were incubated at $37^{\circ} \mathrm{C}$ with $5 \% \mathrm{CO}_{2}$. At specific time points $(4$, $24,48$ and $72 \mathrm{~h})$, the cell culture supernatant $(750 \mu \mathrm{L})$ was removed and stored at $80^{\circ} \mathrm{C}$ until analysis for IL-17A by ELISA. At $72 \mathrm{~h}$ the cells were treated with a 
commercial PMA/ionomycin based stimulation cocktail (eBioscience, UK), to restimulate IL-17 production, and protein transport inhibitor cocktail (eBioscience, UK), to prevent cellular secretion of this IL-17. After $5 \mathrm{~h}$, the cells were washed and stained for analysis of intracellular IL-17, in combination with cell surface markers to identify specific cellular populations, by flow cytometry.

\section{Flow cytometry}

Cells were washed in FACS buffer (PBS, $2 \%$ FCS) and the cell pellets were blocked for 15 minutes at room temperature with anti-CD16/CD32 (eBioscience, UK), then washed again. For cell surface staining cells were incubated for 30 minutes at room temperature with the antibodies against the following: Ly-6G PE, CD11b APC-efluor 660, CD4 PE-Cy7, CD8 PerCP-Cy5.5, NK1.1 PE, biotinylated anti-hematopoietic lineage panel with Streptavidin APC-efluor 780, CD3 APC-Cy7/Pacific Blue, CD8 Pacific Blue, yס TCR APC, CD25 APC-Cy7, CD45 FITC, CD90 APC, CCR6-Alexa Fluor 647, c-KIT APC, NKp46 PE-Cy7, CD127 brilliant violet 421, Sca-1 PE and IL23R PE. For intracellular staining, cells were surface-stained then fixed/ permeabilised using the Foxp3 staining buffer set (eBioscience, UK) according to manufacturer's instructions. Following overnight permeabilisation, antibodies targeting; RORyt PerCP-efluor 710 or IL-17A Pacific blue/ PE were used. Full details of the antibodies utilised within this study are provided in Table E1. Cells were acquired within 24 hours of staining on a FACSCanto II (Becton Dickinson, UK) and data analysed using FlowJo software (FlowJo Inc, OR, USA). 


\section{Quantitative Real Time PCR}

Lung injury was induced with LPS in WT, Rag2 KO and cy Rag2 DKO mice, at $4 \mathrm{~h}$ the lungs collected and stored in RNAlater ${ }^{\mathrm{TM}}$ RNA Stabilisation Reagent (Qiagen, Crawley, UK) at $-20^{\circ} \mathrm{C}$ until ready for use. Total RNA was extracted using the acid phenol method with TRIzol ${ }^{\circledR}$ (Life technologies, UK) according to the manufacturer's protocols before resuspension in RNase-free water. Reverse transcription and quantitative PCR were conducted using the Superscript ${ }^{\circledR}$ III Platinum ${ }^{\circledR}$ One-Step Quantitative RT-PCR System kit (Life technologies, UK) following the manufacturer's instructions. Briefly, $4 \mu \mathrm{l}$ of extracted RNA were added in a PCR plate to $24 \mu \mathrm{l}$ of Reaction mix containing the Taq polymerase, ROX as a reference dye and the primer/TaqMan ${ }^{\circledR}$ mix for either IL-17A or the house-keeping gene YWHAZ. The plate was briefly centrifuged and the reaction performed on a Stratagene MX3005P realtime PCR machine (Aligent Technologies, Germany) by a cycle of 15 min at $50^{\circ} \mathrm{C}$ and $2 \mathrm{~min}$ at $95^{\circ} \mathrm{C}$ for the reverse transcription followed by 45 cycles of $15 \mathrm{~s}$ at $95^{\circ} \mathrm{C}$ and $30 \mathrm{~s}$ at $60^{\circ} \mathrm{C}$. Each sample was run in triplicate for both primers and a nontemplate control was performed. The fold change in IL-17A gene expression levels, relative to a PBS treated control, and normalised to the housekeeping gene YWHAZ, was calculated using the $2^{-\triangle \Delta C T}$ method (9).

\section{Statistical Analyses}

Normally distributed results were compared using Student's t-test or one-way ANOVA. Nonparametric data was normalised prior to analysis, either by log transformed analysis or arcsin transformed in the case of percentage data. The exception to this is the real-time PCR analysis in which mouse strains were 
compared using a Kruskal-Wallis test. All statistical analyses were performed using Prism GraphPad software v.4.0. Graphic data represents the mean ( \pm SEM). 


\section{References}

1. Nakae S, Komiyama Y, Nambu A, Sudo K, Iwase M, Homma I, Sekikawa K, Asano M, Iwakura Y. Antigen-specific T cell sensitization is impaired in IL-17deficient mice, causing suppression of allergic cellular and humoral responses. Immunity 2002;17:375-87.

2. Shinkai Y. RAG-2-deficient mice lack mature lymphocytes owing to inability to initiate V(D)J rearrangement. Cell 1992;68:855-867.

3. Goldman JP, Blundell MP, Lopes L, Kinnon C, Di Santo JP, Thrasher AJ. Enhanced human cell engraftment in mice deficient in RAG2 and the common cytokine receptor gamma chain. Br J Haematol 1998;103:335-42.

4. Suresh Kumar V, Sadikot RT, Purcell JE, Malik AB, Liu Y. Pseudomonas aeruginosa induced lung injury model. $J$ Vis Exp 2014;e52044.doi:10.3791/52044.

5. Iskander KN, Craciun FL, Stepien DM, Duffy ER, Kim J, Moitra R, Vaickus LJ, Osuchowski MF, Remick DG. Cecal ligation and puncture-induced murine sepsis does not cause lung injury. Crit Care Med 2013;41:159-70.

6. Bivas-Benita M, Zwier R, Junginger HE, Borchard G. Non-invasive pulmonary aerosol delivery in mice by the endotracheal route. Eur $J$ Pharm Biopharm 2005;61:214-8.

7. Kimura $\mathrm{R}, \mathrm{Hu} \mathrm{H}$, Stein-Streilein J. Delayed-type hypersensitivity responses regulate collagen deposition in the lung. Immunology 1992;77:550-5. 
8. Matute-Bello G, Downey G, Moore BB, Groshong SD, Matthay MA, Slutsky AS, Kuebler WM. An official American Thoracic Society workshop report: features and measurements of experimental acute lung injury in animals. Am J Respir Cell Mol Biol 2011;44:725-38.

9. Pfaffl MW. A new mathematical model for relative quantification in real-time RT-PCR. Nucleic Acids Res 2001;29:e45. 


\section{Online supplementary figure legends}

SUPPLEMENTARY TABLE E1. Details of the antibodies utilised within this study. Provided is the name, clone, conjugated fluorochrome, isotype and supplier of each all the antibodies that were utilised during this study.

\section{SUPPLEMENTARY FIGURE E1. Flow cytometry gating strategy for determining} the RORyt lymphocytic populations. Lung cells were harvested $24 \mathrm{~h}$ after i.t LPS. Lymphocytes within the lung were characterised. In all histograms both the antibody (black) and an isotype control (red) are shown, for RORyt ${ }^{+}$a fluorescence minus one (light red) control was also included. . Based on the cells forward and side scatter properties a lymphocyte gate was drawn. CD45 staining was used to verify these cells were leukocytes To establish the phenotype of these RORyt ${ }^{+}$cells populations were delineated as $ү \delta \mathrm{TCR}^{+}$( $ү \delta \mathrm{T}$ cells) or $\mathrm{Lin}^{-}$(ILC3s). CD3 expression was then used to define the remaining cell populations; the CD3 positive population was then

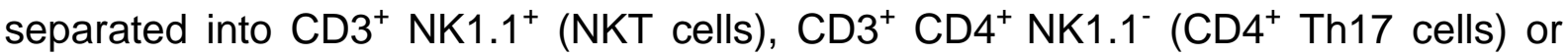
$\mathrm{CD}^{+} \mathrm{CD}^{+} \mathrm{NK}^{-1^{-}}$(CD8 $^{+} \mathrm{Tc17}$ cells). The CD3 negative population was used to define the $\mathrm{CD}^{-} \mathrm{NK}^{-1.1^{+}}$(NK cells).

\section{SUPPLEMENTARY FIGURE E2; Flow cytometric gating strategy for identifying} RORyt $^{+}$ILCs and phenotyping based on the expression of typical of known group 3 innate lymphoid cell populations. (A) ILCs recruited to the lung during acute lung injury were identified as being $\operatorname{Lin}^{-}\left(\mathrm{CD} 3^{-} \mathrm{Gr}-1^{-} \mathrm{CD} 11 \mathrm{~b}{ }^{-} \mathrm{TER}-11^{-} \mathrm{B} 220^{-} \mathrm{NK} 1.1^{-}\right.$ yठTCR ${ }^{-}$CD11c'), CD45 ${ }^{+}$, RORyt $^{+}$. Expression of RORyt shown in the dot plot is compared to an isotype control (red). The expression of cell surface markers (B) CD90 (alloantigen Thy-1), (C) Sca-1, (D) NKp46 (NCR), (E) CD117 (c-kit), (F) CD127 
( $\alpha$ - chain of the receptor for IL-7), (G) CCR6. (black line) compared to isotype control (red shaded) associated with ILC3 subsets characterised (representative histograms shown). The data is representative of three independent experiments, each experiment utilised $\mathrm{n}=3$ mice pooled. 


\section{SUPPLEMENTARY TABLE E1}

\begin{tabular}{|c|c|c|c|c|}
\hline Antibody & Clone & Fluorophore & Isotype control & Supplier \\
\hline CD117 (Ckit) & 2B8 & APC & Rat lgG2b K & BioLegend \\
\hline CD11b & $\mathrm{M} 1 / 70$ & APC efluor 660 & Rat IgG2b & eBioscience \\
\hline CD127(IL-7R) & A7R34 & BV421 & Rat IgG2a $\mathrm{K}$ & BioLegend \\
\hline CD196 (CCR6) & 29-2L17 & Alexa Fluor 647 & $\begin{array}{l}\text { Armenian } \\
\text { Hamster IgG }\end{array}$ & BioLegend \\
\hline CD25 & PC61 & APC-Cy7 & Rat IgG1 & BioLegend \\
\hline CD3 & $17 \mathrm{~A} 2 ; 145-2 \mathrm{C} 11$ & $\begin{array}{l}\text { Pacific Blue/ } \\
\text { APC-Cy7 }\end{array}$ & $\begin{array}{l}\text { Rat IgG2b k/ } \\
\text { Armenian } \\
\text { Hamster lgG }\end{array}$ & BioLegend \\
\hline CD4 & GK1.5 & $\begin{array}{l}\text { PE-Cy7/ } \\
\text { Pacific Blue }\end{array}$ & Rat IgG2b, $\mathrm{k}$ & eBioscience \\
\hline CD45 & $30-F 11$ & FITC & Rat IgG2b, $\mathrm{K}$ & BioLegend \\
\hline CD8a & $53-6.7$ & $\begin{array}{l}\text { Pacific Blue/ } \\
\text { PerCP-Cy5.5 }\end{array}$ & Rat IgG2a $\mathrm{k}$ & $\begin{array}{l}\text { BioLegend/ } \\
\text { eBioscience }\end{array}$ \\
\hline CD90.2 & $30-\mathrm{H} 12$ & APC & Rat IgG2b, $\mathrm{k}$ & BioLegend \\
\hline IL-23R & O78-1208 & PE & Rat IgG1 & $\begin{array}{l}\text { Becton } \\
\text { Dickenson }\end{array}$ \\
\hline Ly-6A/E (Sca-1) & D7 & $\mathrm{PE}$ & Rat IgG2a k & BioLegend \\
\hline Ly-6G (GR-1) & RB6-8C5 & PE & Rat IgG2b, $k$ & eBioscience \\
\hline NK1.1 & PK136 & $\mathrm{PE}$ & Mouse IgG2a k & eBioscience \\
\hline NKp46 (CD335) & $29 \mathrm{~A} 1.4$ & PE-Cy7 & Rat IgG2a k & BioLegend \\
\hline үठTCR & GL3 & APC & $\begin{array}{l}\text { Armenian } \\
\text { Hamster IgG }\end{array}$ & BioLegend \\
\hline $\begin{array}{l}\text { Mouse Hematopoietic } \\
\text { Lineage Panel: CD3, } \\
\text { CD45R, CD11b, } \\
\text { Erythroid marker, Ly6G } \\
\text { Supplemented with } \\
\text { NK1.1 \& үסTCR }\end{array}$ & $\begin{array}{l}\text { 145-2C11, RA3-6B2, } \\
\text { M1/70, TER-119, RB6- } \\
\text { 8C5 } \\
\text { PK136, GL3 }\end{array}$ & $\begin{array}{l}\text { Biotin \& } \\
\text { Streptavidin } \\
\text { APC-efluor } 780\end{array}$ & $\begin{array}{l}\text { Streptavidin only } \\
\text { control }\end{array}$ & eBioscience \\
\hline RORyt & B2D & PerCP-efluor 710 & Rat lgG1 K & eBioscience \\
\hline IL-17A & eBio17B7 & $\begin{array}{l}\text { Pacific blue or } \\
\text { PE }\end{array}$ & Rat IgG2a k & eBioscience \\
\hline
\end{tabular}


Figure E1

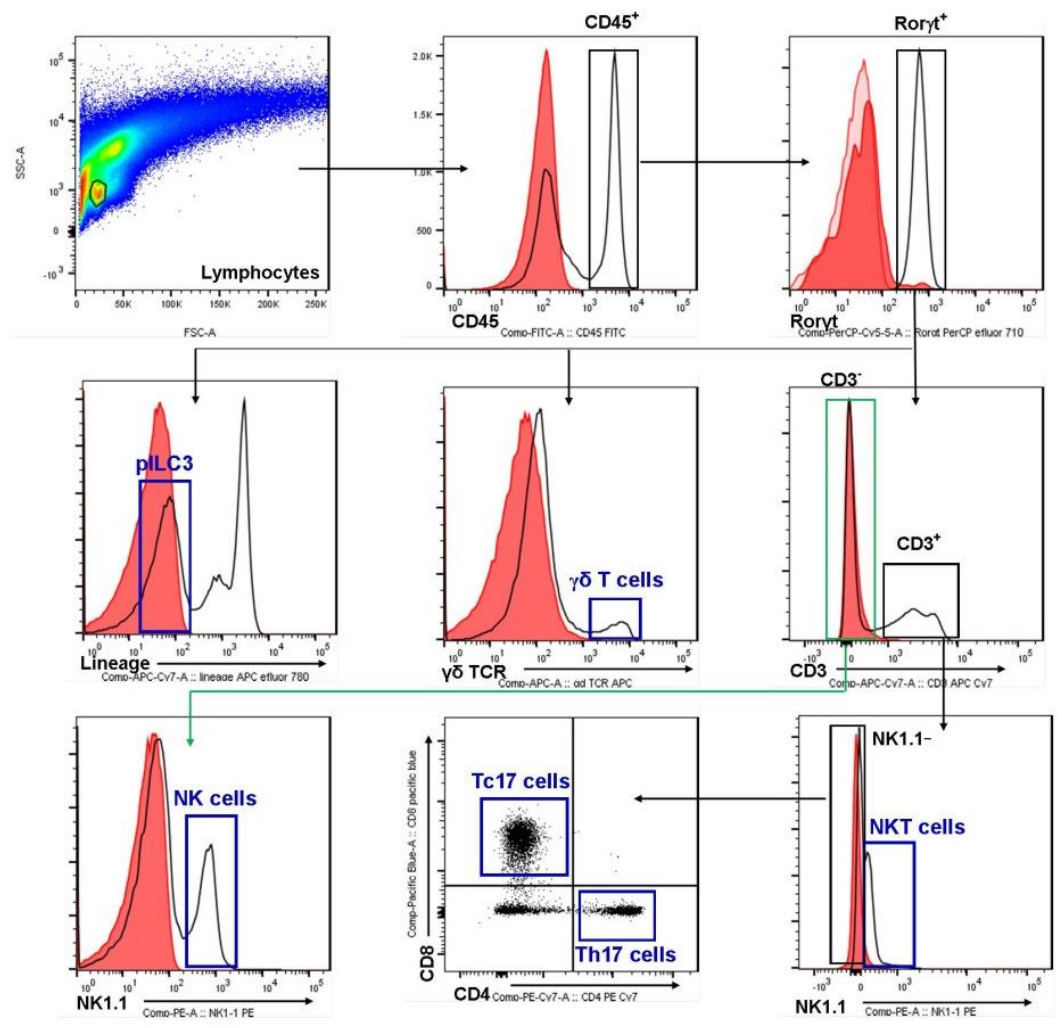


Figure E2
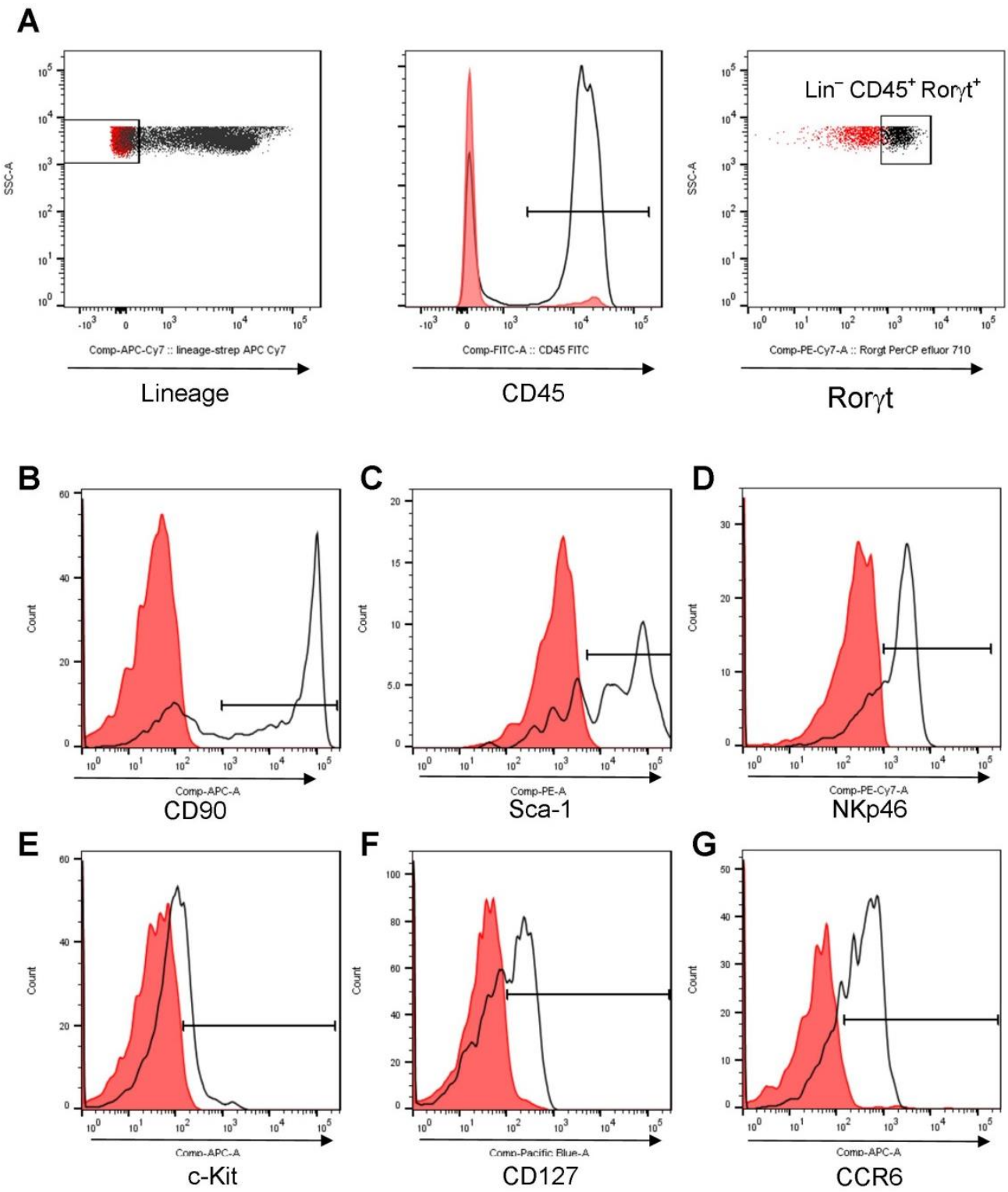